\title{
Assessment of selected physicochemical properties of restorated water of the Mogileńskie Lake
}

\author{
Krzysztof Berleć ${ }^{1, *}$, Bożena Szejniuk ${ }^{1}$, and Magdalena Michalska ${ }^{1}$ \\ ${ }^{1}$ Department of Animal Hygiene and Environmental Microbiology, University of Technology and \\ Agriculture in Bydgoszcz, Poland
}

\begin{abstract}
Excessive supply of nutrients contributes to gradual eutrophication of water. This process can happen fast, especially in shallow lakes which are more prone to degradation. This also causes deterioration of settlement conditions of many organisms and limits economic use of water. Eutrophication can lead to gradual shallowing and shrinking of water reservoirs and subsequently disappearance of lakes. Therefore, appropriate diagnosis and reduction of the amount of pollutantsflowing into lakes are crucial for the water quality improvement and prevention from further degradation. The Mogileńskie Lake, like many other town lakes was supplied with sewage. As a consequence, the reservoir stopped being an attractive urban element, and became an object cumbersomeand dangerous to the residents health. For this reason the lake has been subjected to many protection and reclamation processes. The water samples were taken 10 times from 3 sampling points between September 2014 and June 2015. The contents of total phosphorus, phosphorates, total nitrogen, nitrates, nitrites, and ammonium nitrogen was measured in the tested water. The results obtained from the water analyzed for biogenic elements, and their compounds indicate low effectiveness of the carried out reclamation. According to many authors, the choice of artificial aeration as a reclamation process for the Mogileńskie Lake was a mistake.This cleaning method does not provide the expected results when used for shallow and polymictic lakes, especially in combination with an invasive method of dredging and the controversial deposing of the extracted residues in the direct proximity of the lake.
\end{abstract}

\section{Introduction}

Location of lakes in land depressions makes them a natural settling tanks, which accommodate sedimenting suspensions and compounds both those from the catchment and those produced inside the lake. A significant amount of biogenic substances accumulates in the form of bottom sediment, which is caused by pollutants flowing to the reservoir. In

\footnotetext{
* Corresponding author: kberlec@,wp.pl
} 
oxygen free conditions, readily biodegradable organic compounds deposited in the sediment can be released and go up penetrating the water above the bottom, thus becoming a source of internal load of substances maintaining a high trophic level and low quality of water [1]. Small and shallow lakes are most frequently affected by the eutrophication process, whereas large and deep ribbon lakes are most resistant to it.

This process has been dramatically accelerated by the changes in catchment management, forest cutting and increase in farmlands. Furthermore, application of fertilizers, large scale farming and melioration of farmlands have also contributed to the process of eutrophication. Additionally, urbanization accompanied with dumping sewage has taken its toll on lakes and rivers [2].

Reclamation of lakes aims at reversing, stopping or at least slowing down the process of lakes eutrophication, and sometimes removal of its negative effects. Protection of water reservoirs involves limiting inflow of biogenic and organic substances from a catchment, whereas all reclamation methods are to be used within the lake basin, and protection methods in adjacent areas [3].

The study attempts to make the initial assessment of the Mogileńskie Lake reclamation effectiveness on the basis of the analysis performed on selected physical and chemical indexes of water quality.

\section{Background of the research}

The research object was water from the Mogileńskie Lake, situated in Kujawsko-Pomorskie Voivodeship. The lake water overcame the reclamation process. The area is part of the Wielkopolskie Lake District macroregion and the Gnieźnieńskie Lake District mesoregion. The lake belongs to the Odra-Warta-West Noteć-Panna basin.

The lake belongs to the Mogilno city and borough. The area of the lake is 43.8 ha, with an average depth of $3.2 \mathrm{~m}$, and the maximum of $6.8 \mathrm{~m}$. It is south oriented and lies approximately $7 \mathrm{~km}$ from the paralelly situated Noteć river [4].

Restoration of the Mogileńskie Lake started in 1991 and included three fundamental steps:

- increasing the depth of the downtown, shallow part of the lake;

- protection of the remaining part of the lake from contamination due to dredging works;

- restoration of the entire lake after dredging.

Properly designed reclamation process consists of a few stages. The first stage involves precisely defining the scale of the problem. The second stage involves determining degradation degree of the lake, level of hydrobiological structure loss, and the scope of its function and processes disruption. At the third stage goal should be established. What and for how long has to be fixed in the lake - drainage basin system.

The fourth stage involves an analysis of the possibilities of achieving the goal and choosing the right methods, establishing schedule of works and procedures to be used, as well asidentifying possible side effects. A further stage involves creation of a project, identification of necessary administrative operations, possible repetitions of procedures, securing funds and technical means, as well as employing specialists and institutions to implement the project. The last stage involves conducting of the procedure and its supervision, monitoring effects during work and few seasons after it. [5]

The accepted reclamation project assumed the use of diflox devices for aeration, dredging and installation of Bio-Hydro structures.

Aeration prevents and liquidates negative processes occurring in still waters and boosts 
natural process of a trophic chain, leading to management of readily biodegradable organic compounds [6].

Cleaning water by means of Bio-Hydro barriers, made from panels hung to floating tubes, involves adding adequately arranged artificial substrate structures, where periphyton, plant and animal organisms filtering water can settle [4].

The project assumed two steps reclamation, where the first step include the reclamationof the lake's downtown part usingthe dredging method [4]. To prevent stirred sediment from getting into the lake, it was divided with a barrier consisting of six difloxes. The extracted sediments were deposited in the lowered part of the park adjacent to the lake. After having deepened the downtown part of the lake, it was temporarily separated from its remaining part by a double barrier made of Bio-Hydro structures. Inside the barrier three difloxes were placed and intensive aeration was started.

\section{Research methodology}

The examination was carried out between September 2014 and June 2015, and was supposed to define the content of: total phosphorus, phosphorates, total nitrogen, nitrates, nitrites and ammonium nitrogen in the water.

The water samples were collected in monthly intervals, from three $20 \mathrm{~cm}$ deep points (Fig.1) to sterile, 0.5 liter bottles. The bottles were filled up with water, hermetically closed, secured from light, cooled down to temperature of $4{ }^{\circ} \mathrm{C}$ and transported to the laboratory where tests were performed. The time from the collection to the performance of analyses did not exceed 24 hours.

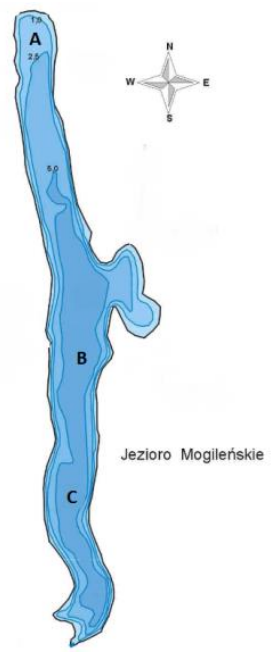

Fig. 1. Water sampling points.

An analysis of the contents of total phosphorus, phosphorates, total nitrogen, nitrates, nitrites and amonnium nitrogen was carried out by the spectrophotometric method with the use ofthe NOVA 400 spectrophotometer, whereas the content of total nitrogen in mineralized samples was performed by the Kjeldahl method, with accordance to PN 73/C04576.12 norm. For measurements of the indexes mentioned above the pre-prepared calibration Merck kits were used. 
Total phosphorus - water solution $\left(100 \mathrm{~cm}^{3}\right)$ and concentrated $\mathrm{HCl}\left(15 \mathrm{~cm}^{3}\right)$ was vaporized, and then the sample - with addition of concentrated $\mathrm{H}_{2} \mathrm{SO}_{4}$, was mineralized. For the purpose of discoloration, $2 \mathrm{~cm}^{3}$ of concentrated $\mathrm{H}_{2} \mathrm{O}_{2}$ was added, After the process of mineralization, the sample was put in a $100 \mathrm{~cm}^{3}$ volumetric flask and filled up with distilled water. The samples were measured for total phosphorus with the usage of the colorimetric method (PN 91-C/-04537.09).

Phosphorates - orthophosphate ions enter into reaction with molybdenum ions in a solution acidificated with sulphur acid, forming molybdenum-phosphoric acid. The acid is reduced with ascorbic acid with the use of phosphomolybdenium blue (PMB), which is measured photometrically. A filtered sample was taken out of the refrigerator prior to the analysis to reach the temperature in the range of $10-35^{\circ} \mathrm{C}$. A $5 \mathrm{ml}$ sample was placed in a beaker and 5 drops of P-1A were added. Then the solution was shaken. Next, 1 micro spoon of P-2A was added and solution was mixed until the dissolution of the reagent. After 5 minutes, the sample was taken to a $10 \mathrm{~mm}$ dish and measured in a spectrophotometer.

Nitrate nitrogen - in a solution acidified by sulphuric and phosphoric acids react with 2.6-dimethylphenol forming an orange colored solution of 4-nitro2.6dimethyphenol. Preparation of the sample involved introduction of $4 \mathrm{ml} \mathrm{NO}$-1reagent into the flask and along with tested water with the temperature of $20^{\circ} \mathrm{C}$. The next step involved introduction of $0.5 \mathrm{ml}$ of $\mathrm{NO}_{3}-2$ reagent and thorough mix of the sample. After 10 minutes measurement was performed with the use of $10 \mathrm{~mm}$ tray and wave length of $338 \mathrm{~nm}$.

Nitrite nitrogen - in alkaline environment nitrite ions react with sulphanilic acid forming diasonic salt, which reacts with $\mathrm{N}-(1-$ naphtylo)ethylenediaminedihydrochloride yielding an azo dye of red-purple color. The procedure involved introducing $5 \mathrm{ml}$ of the tested sample with the temperature of $20^{\circ} \mathrm{C}$ and adding $\mathrm{NO}_{2}-\mathrm{AN}$ reagent, and thorough mixing until total dissolution of the reagent. During the next stage the sample was put aside for 10 minutes. Thenmeasurements were performed with the use of $10 \mathrm{~mm}$ long tray and wave length of $338 \mathrm{~nm}$.

Ammonium nitrogen - occurs partly in the form of ammonium ions and partly in the form of ammonium. Between these two forms there is an equilibrium dependent on $\mathrm{pH}$. In strongly alkaline solutions ammonium nitrogen occurs mainly in the form of ammonium which reacts with a chlorinating agent and forming monochloroamine. It then reacts with thymol forming blue dye, which is a derivative of indophenol, measured photomethrically. $0.6 \mathrm{ml}$ of $\mathrm{NH}_{4}-1$ reagent was added to a test tube with $0.5 \mathrm{ml}$ of water and mixed. Next, a flat spoon of $\mathrm{NH}_{4}-2$ reagent was added and vigorously shaken until complete dissolution of the reagent was achieved. After 5 minutes, 4 drops of $\mathrm{NH}_{4}-3$ reagent were added, the contents were then mixed and put aside for another 5 minutes.

\section{Results and discussion}

The authors' own tests of trophic determinants of water quality have proved that their levels usually exceeded the normative values of cleanliness defined forthe surface water of class III.

Apart from phosphorus, productivity of water is affected by nitrogen and its compounds. In nature, nitrogen is subject to cyclical circulations which involve many biochemical processes. Inland waters contain nitrogen in its mineral and organic forms. Mineral nitrogen compounds include ammonium nitrogen, nitrates and nitrites, whereas nitrites occur in lakes as a temporary form and their quantities are small. Nearly50\% of the whole nitrogen content consists of organic compounds with concentration changes 
depending on the intensity of life processes in the reservoir. The content of mineral nitrogen in water undergo significant changes throughout the year [2].

In the carried out tests, the highest concentration of total nitrogen $\left(18.2 \mathrm{mg} / \mathrm{dm}^{3}\right)$ was found in February, whereas, the lowest $\left(15.2 \mathrm{mg} / \mathrm{dm}^{3}\right)$ in May (Table 1). The average concentration of total nitrogen was $17.06 \mathrm{mg} / \mathrm{dm}^{3}$. Slightly lower values in the study of the waters of the Mogileńskie lake were reported by Berleć et al. [7] which reached respectively: $17.9 \mathrm{mg} / \mathrm{dm}^{3}, 10.4 \mathrm{mg} / \mathrm{dm}^{3}$ and $14.78 \mathrm{mg} / \mathrm{dm}^{3}$. The tests performed by Gawrońska et al [8] for the water of the Głęboczek Lake a few years after its reclamation have proven that the level of nitrogen in surface waters was $0.075-0.125 \mathrm{mgdm}^{3}$. Tests carried out by Gawrońska et al [9] for the Długie Lake in Olsztyn have also indicated high concentrations of total nitrogen. Before undertaking the task of cultivation in 1972, the content of total nitrogen was in the range of 3.5 to $12.5 \mathrm{mg} / \mathrm{dm}^{3}$ in surface layers. After cutting off the inflow of sewage, the water underwent successive analyses in 1974-1976. The values of total nitrogen concentration presented themselvesrespectively: 2.6-21.5 $\mathrm{mg} / \mathrm{dm}^{3}$ in $1974,1.9-12.6 \mathrm{mg} / \mathrm{dm}^{3}$ in $1975,2.1-18.2 \mathrm{mg} / \mathrm{dm}^{3}$ in 1976. After next reclamation processes, the concentration of total nitrogen did not exceed $2.0 \mathrm{mg} / \mathrm{dm}^{3}$. Gołdyn and Messyasz [10] found the content of nitrogen in the water ofthe Durowskie Lake to be at the level from $2.18 \mathrm{mg} / \mathrm{dm}^{3}$ to $5.25 \mathrm{mg} / \mathrm{dm}^{3}$. The highest values were reported in the summer when they should be the lowest.

The concentration of nitrates and other pollutants accumulated in surface water undergoes significant changes throughout the year. Nitrate nitrogen, which dissolves well in water, has a large influence on productivity of the water ecosystems. Agricultural activity is viewed as a source of nitrogen compounds in water, both ground and surface water, which is the result of using excessive quantities of this component. Undoubtedly, several forms of nitrogen depend onits washing out from the soil. The amount of nitrogen loss is connected with the soil quality class, plant coverage and the utilization manner. It appears that in light soils as much as $98 \%$ of nitrogen and $7.7 \%$ of phosphorus is washed out [11]. In the whole spectrum of nitrogen compounds, special focus is put on the content of nitrates which being well soluble easily migrates along with the water flowing down from farmlands [12].

Table 1. The content of nitrogen compounds in the waters of the Mogileńskie Lake.

\begin{tabular}{|c|c|c|c|c|c|c|c|c|c|c|c|}
\hline \multirow{2}{*}{ Parameter } & \multirow{2}{*}{$\begin{array}{c}\text { Sampling } \\
\text { place }\end{array}$} & \multicolumn{10}{|c|}{ Sample number } \\
\hline & & 1 & 2 & 3 & 4 & 5 & 6 & 7 & 8 & 9 & 10 \\
\hline \multirow{3}{*}{$\begin{array}{c}\mathrm{N}_{\text {tot }} \\
{\left[\mathrm{mg} / \mathrm{dm}^{3}\right]}\end{array}$} & A & 16.1 & 16.5 & 16.9 & 17.8 & 18.1 & 18.2 & 17.9 & 16.8 & 16.5 & 15.2 \\
\hline & B & 15.8 & 16.9 & 17 & 17.3 & 17.7 & 17.3 & 17.6 & 17.2 & 16.9 & 17 \\
\hline & $\mathrm{C}$ & 15.9 & 17.1 & 17.5 & 17.4 & 17.7 & 17.8 & 17.7 & 16.9 & 16.8 & 16.3 \\
\hline \multirow{3}{*}{$\begin{array}{c}\mathrm{N}-\mathrm{NO}_{3} \\
{\left[\mathrm{mg} / \mathrm{dm}^{3}\right]}\end{array}$} & A & 7.7 & 7.9 & 7.8 & 8.3 & 10.2 & 10.5 & 10.2 & 8.9 & 8.8 & 8.2 \\
\hline & B & 7.7 & 7.6 & 7.7 & 8.4 & 9.8 & 10.1 & 10.1 & 8.1 & 8.4 & 8.5 \\
\hline & $\mathrm{C}$ & 7.5 & 7.5 & 7.9 & 8.1 & 9.7 & 9.7 & 9.8 & 8.3 & 8.3 & 8.4 \\
\hline \multirow{3}{*}{$\begin{array}{c}\mathrm{N}-\mathrm{NO}_{2} \\
{\left[\mathrm{mg} / \mathrm{dm}^{3}\right]}\end{array}$} & A & 0.16 & 0.21 & 0.22 & 0.3 & 0.33 & 0.29 & 0.28 & 0.29 & 0.25 & 0.23 \\
\hline & $\mathrm{B}$ & 0.16 & 0.18 & 0.25 & 0.29 & 0.34 & 0.29 & 0.3 & 0.28 & 0.27 & 0.22 \\
\hline & $\mathrm{C}$ & 0.18 & 0.22 & 0.21 & 0.29 & 0.31 & 0.3 & 0.27 & 0.26 & 0.24 & 0.19 \\
\hline \multirow{3}{*}{$\begin{array}{c}\mathrm{N}-\mathrm{NH}_{4} \\
{\left[\mathrm{mg} / \mathrm{dm}^{3}\right]}\end{array}$} & A & 0.09 & 0.11 & 0.14 & 0.2 & 0.21 & 0.22 & 0.17 & 0.18 & 0.11 & 0.12 \\
\hline & $\mathrm{B}$ & 0.09 & 0.13 & 0.15 & 0.19 & 0.21 & 0.19 & 0.19 & 0.15 & 0.12 & 0.12 \\
\hline & $\mathrm{C}$ & 0.1 & 0.12 & 0.16 & 0.19 & 0.2 & 0.19 & 0.17 & 0.15 & 0.13 & 0.14 \\
\hline
\end{tabular}


In the carried out tests, the content of nitrates appeared from 7.5 to $10.5 \mathrm{mg} / \mathrm{dm}^{3}$, with the average $8.67 \mathrm{mg} / \mathrm{dm}^{3}$ for the whole period. According to tests carried out by Lossowa et al [13], the level of nitrates after reclamation of the Głęboczek Lake was measured between $0.12-0.71 \mathrm{mg} / \mathrm{dm}^{3}$ between March and May. According to a regulation of the Minister of the Environment, the level of nitrates in cleanliness class I of inland water should not exceed $5.0 \mathrm{mg} / \mathrm{dm}^{3}$. The obtained results defy effectiveness of the methods chosen for reclamation of the Mogileńskie Lake. Comparing these limits with the authors' own tests results, we can ascertain that the content of nitrates in the Mogileńskie Lake complies with the required limits. Occurrence of nitrates in surface waters, mainly in lakes, is considered to accelerate euthrophication. The opinions on the subject of concentrations that cause euthrophication vary, the values differ in terms of hundredth and tenth of $\mathrm{mg} / \mathrm{dm}^{3}$ [14].

Transitional product of nitrogen compounds transformation in surface waters are nitrites characterized by short life. Their presence indicates a current inflow of anthropogenic originpollution. They are quickly reduced to ammonium, and in oxygen condition they undergo oxidization to transform to nitrates [15]. During the tests their content maintained at a similar level, from 0.09 to $0.22 \mathrm{mg} / \mathrm{dm}^{3}$, with the average $0.15 \mathrm{mg} / \mathrm{dm}^{3}$ for the whole period. Slightlybetter effect of reclamation was achieved forthe Głęboczek Lake where Lossow et al. [13] defined concentration at the level of $0.016-0.013 \mathrm{mg} / \mathrm{dm}^{3}$. The results of nitrites obtained in those tests classify the Głęboczek lake in cleanliness classIII, in contrast to the Mogileńskie Lake which water cannot be classified with this parameter. Also tests of Powidzkie and Mąkolskie water revealed poor results, where the average content of nitrites was $0.00045 \mathrm{mg} / \mathrm{dm}^{3}$ and $0.0081 \mathrm{mg} / \mathrm{dm}^{3}$ respectively [16,17].

Presence of ammonium nitrogen indicates water pollution by domestic or industrial waste water, which additionally in the presence of oxygen stimulates growth of nitrification bacteria. Presence of this compound was reported in the authors' own tests at the level of 0.09 to $0.21 \mathrm{mg} / \mathrm{dm}^{3}$ - on average $0.12 \mathrm{mg} / \mathrm{dm}^{3}$.

A several times higher content of ammonium nitrogen was reported in the reclaimed Rudnickie Lake Mientki [18]. The content at the level, from $1.1 \mathrm{mg} / \mathrm{dm}^{3}$ to $12.3 \mathrm{mg} / \mathrm{dm}^{3}$, was explained by a sudden supply of sewage from a sugar mill. In the view of reclaimed lake water protection, it is interesting that the contamination occurred in the stage II of the process, whenwater-sewage system of the catchment was theoretically arranged. Before that incident, the amount of ammonium nitrogen was between 2.1 and $4.2 \mathrm{mg} / \mathrm{dm}^{3}$. Results slightly above than those obtained in the authors' own tests were reported by Gołdyn and Messyasz [10], who while testing the water from the Durowskie lake, which had been prepared for reclamation, discovered the presence of this form of nitrogen compounds to be at the level of $0.23 \mathrm{mg} / \mathrm{dm}^{3}$ in October $2005,0.57 \mathrm{mg} / \mathrm{dm}^{3}$ in November, and up to $1.2 \mathrm{mg} / \mathrm{dm}^{3}$ in January 2006. In their opinion, the increase was caused by supplying the surface water with hypolimnion (water mixing) with high concentration of ammonium nitrogen and by formation of ice cover preventing water from waving and subsequent oxygenation. Since March the content of ammonium nitrogen started to drop gradually.

The highest threat to lakes is a progressing intensification of farming. It causes their gradual disappearance which is a direct effect of excessive use of phosphorous fertilizers [19].

On the basis of his research, Maehl [20] noticed that the content of phosphorus from 0.05 to $0.15 \mathrm{mg} / \mathrm{dm}^{3}$ guaranteesthe appropriate transparency of water in shallow lakes. In the authors' own tests total phosphorus was from 0.43 to $0.80 \mathrm{mg} / \mathrm{dm}^{3}$ (Table 2). Its highest concentration throughout the period of testing was reported in February at all control points.

This element, as compared to others, occurs in surface waters in smaller concentration, though it is one of the most indispensible elements for living organisms [21]. According to 
Gałczyński [22], the limit value for phosphorus above which the process of a water reservoirover fertilization takes place is over $0.1 \mathrm{mg} / \mathrm{dm}^{3}$. Szatten [23] in tests of the water from the reclaimed Głęboczek Lake found that concentration from $0.07 \mathrm{mg} / \mathrm{dm}^{3}$ (in spring) to $0.08 \mathrm{mg} / \mathrm{dm}^{3}$ (in summer) is satisfactory. In the same tests the content of total phosphorus in the lake reached the maximum value of $1.01 \mathrm{mg} / \mathrm{dm}^{3}$ in late spring - as in the authors' own tests. The average concentration of phosphorus was $0.32 \mathrm{mg} / \mathrm{dm}^{3}(0.29$ in own tests), classifying the lake water belowthe expected quality [24].

Table 2. The content of phosphorus compounds in the waters of the Mogileńskie Lake.

\begin{tabular}{|c|c|c|c|c|c|c|c|c|c|c|c|}
\hline \multirow{2}{*}{ Parameter } & \multirow{2}{*}{$\begin{array}{c}\text { Sampling } \\
\text { place }\end{array}$} & \multicolumn{10}{|c|}{ Sample number } \\
\hline & & 1 & 2 & 3 & 4 & 5 & 6 & 7 & 8 & 9 & 10 \\
\hline \multirow{3}{*}{$\begin{array}{c}\mathrm{P}_{\mathrm{tot}} \\
{\left[\mathrm{mg} / \mathrm{dm}^{3}\right]}\end{array}$} & A & 0.48 & 0.53 & 0.62 & 0.66 & 0.75 & 0.80 & 0.73 & 0.55 & 0.49 & 0.43 \\
\hline & B & 0.43 & 0.50 & 0.59 & 0.66 & 0.76 & 0.79 & 0.75 & 0.60 & 0.51 & 0.47 \\
\hline & $\mathrm{C}$ & 0.43 & 0.50 & 0.58 & 0.62 & 0.73 & 0.75 & 0.75 & 0.61 & 0.50 & 0.46 \\
\hline \multirow{3}{*}{$\begin{array}{c}\mathrm{P}_{-} \mathrm{PO}_{4} \\
{\left[\mathrm{mg} / \mathrm{dm}^{3}\right]}\end{array}$} & A & 0.26 & 0.28 & 0.26 & 0.34 & 0.31 & 0.33 & 0.28 & 0.28 & 0.26 & 0.25 \\
\hline & B & 0.22 & 0.27 & 0.27 & 0.28 & 0.26 & 0.29 & 0.24 & 0.25 & 0.22 & 0.24 \\
\hline & $\mathrm{C}$ & 0.23 & 0.27 & 0.26 & 0.27 & 0.31 & 0.31 & 0.27 & 0.26 & 0.24 & 0.23 \\
\hline
\end{tabular}

Elevated content of phosphorates reflects the high intensity of processes connected to the decomposition of organic forms of phosphorus (discharging phosphorus compounds from bottom sediments to the water) and thus their immediate readiness to be used for the primary production of the lake [1]. According to the carried tests, their level ranged from 0.22 to $0.29 \mathrm{mg} / \mathrm{dm}^{3}$ with an average $0.27 \mathrm{mg} / \mathrm{dm}^{3}$ for the testing period. Such an intensive increase in the concentration of phosphorates in the period of late spring could have been caused by the inflow of a significant load of organic pollutionfrom numerous farmlands in the lake catchment or adverse weather conditions, which most probably delayed the plants vegetation period, according to Goszczyński [25]. The same author reported the content of phosphorates to be from 0.042 to $0.111 \mathrm{mg} / \mathrm{dm}^{3}$ in the Głęboczek Lake during springmixing which exceeded norms defined for the lowest cleanliness class III. Observations of phosphorates content changes in the Głęboczek Lake during and afterreclamation by the method of phosphorus inactivation were carried out by Lossow et al. [26]. He proved that in spring 2002 and 2003 orthophosphorates were not discovered which according to the authors means that the reclamation was properly done. For the effectiveness of reclamation spoke results of tests for phosphorus content inthe Mąkolno Lake $\left(0.014 \mathrm{mg} / \mathrm{dm}^{3}\right)$ and the Powidzkie Lake $\left(0.0013 \mathrm{mg} / \mathrm{dm}^{3}\right)$ [16,17]which compared to the reclaimed lakes were slightly affected by external factors. Thus these values were definitely lower than those for the Mogileńskie Lake $\left(0.2 \mathrm{mg} / \mathrm{dm}^{3}\right.$ on average), especially in the second reservoir (Prowidzkie) which is considered to be one of the cleanest water reservoirs in Wielkopolska.

\section{Conclusions}

Anthropogenic evolution of surface water is one of the crucial problems in the modern world. The best example of this are water reservoirs located in the city centers or outskirts. Their resistance to degradation is determined by natural characteristics. Low lake resilience to the degradation influence causes low effectiveness of reclamation processes which is why it might not have an effect on planned changes to the water quality. 
The choice of artificial aeration as a reclamation method for the Mogileńskie Lake was a mistake, because this cleaning method does not provide the expected effects in case of shallow and polymictic lakes.

The attempt to improve trophic conditions of the lake without applying procedures to protect it from supply of biogenic compounds and pollutants doomed the investment to failure.

To improve the situation of a degraded lake it is not enough to restore it to the state before degradation. Many feedback loops in the lake sustain its state after introduction of changes, and lakes reveal resilience to restoration treatment. We need to remember that these are biological elements and subsequent processes occurringin the water ecosystem that stabilize and sustain the existing state. Undertaking reclamation actions without a profound knowledge of biological conditionings usually do not provide expected effects. What is more, it can push the ecosystem into a state that would be completely different from the expected one, even more difficult to repair.

\section{References}

1. E. B. Welch, K. Cooke, Lake Reserv. Manage., 21, 209-217, (2005)

2. J. Kohler, S. Hilt, R. Adrian, A. Nicklish, H. P. Kozerski, N. Walz, Freshwat. Biol. 50, 10, 1639-1650, (2005)

3. A. Policht-Latawiec, A.Bogdał, W. Kanownik, T. Kowalik, K. Ostrowski, P. Gryboś, Ann.Set. Environ.Prot 16, 546-561(2014)

4. J.Wysocki, J.Gromadzki, M.Zawadzki, Eko-Tech, Warszawa (1991)

5. R.Wiśniewski,: Przeg. Kom. 7, 190, 18 (2007)

6. J.Jerzy, J.Wysocki, Urzadzenie do napowietrzania niestratyfikowanych akwenów wód stojacych. P-331159, (2006)

7. K. Berleć, A. Traczykowski, K. Budzińska, B. Szejniuk, M. Michalska, A. Jurek, M. Sulewski, Przem. Chem. 94, 11, (2015)

8. H.Gawrońska, K.Lossow, J.Grochowska, R.Brzozowska, Mat. Konf. Nauk.-Tech., nt. „Ochrona i rekultywacja jezior”, 11-13 maj, Grudziądz (2004)

9. H.Gawrońska, K. Lossow, J.Grochowska, Wyd. Edycja, Olsztyn (2005)

10. F. Gołdyn, B. Messyasz Stan jakości wód i możliwości rekultywacji jeziora Durowskiego. Maszynopis. 1-48. UAM Poznań 2008

11. B.Szpakowska, B.Karlik, W.Gaca, Zesz. Nauk. AR w Krakowie 404, 347-354, (2003)

12. T.Hus, K. Pulikowski, Pol J Environ Stud., 20, 4, 895-902, (2011)

13. K. Lossow, H.Gawrońska, M. Łopata, B. Jaworska, UWM. Olsztyn (2002)

14. A. Karwacka, P. Niedzielski, R. Staniszewski. Ann.Set. Environ.Prot. 17, 1684-1698, (2015)

15. P.Kułakowski, A.Biernacka, GWiTS, 9, 2-7, (2007)

16. Sprawozdanie z badań $n r 185 / 2008$., WIOŚ Poznań - Delegatura w Koninie

17. Sprawozdanie z badań monitoringowych Jeziora Powidzkiego w 2009 roku. Dział Monitoringu WIOŚ Poznań - Delegatura w Koninie

18. C.Mientki,; Mat. Konf. Nauk-Techn. nt. „Ochrona jezior ze szczególnym uwzględnieniem metod rekultywacji”, 123 - 130, Przysiek, (2000)

19. A. Policht-Latawiec, W. Żarnowiec, Z. Perec-Krupa, Wod.Środ. Obsz. Wiej. 17, 4. 111-128, (2017)

20. P. Maehl, Mat. Konf. Nauk-Tech., nt. „Ochrona i rekultywacja jezior”, 12-14 czerwiec, Przysiek (2000)

21. W.Balcerzak,: Monografia 373. Wyd. PK. Kraków (2009) 
22. Ł. Gałczyński, GWiTS, 12, 34-37 (2008)

23. D. Szatten, Insp. Ochr.Środ., Bydgoszcz (2008)

24. D. Szatten, WIOŚ w Bydgoszczy (2010)

25. J. Goszczyński, Mat. Konf. Nauk-Tech., nt. „,Ochrona i rekultywacja jezior”, 12-14 czerwiec, Przysiek (2000)

26. K. Lossow, H.Gawrońska, M.Łopata, B.Jaworska, Mat. Konf. Nauk.-Tech., nt. „Ochrona i rekultywacja jezior”, 11-13 maj, Grudziądz (2004) 